\title{
Gambling problems in primary care: A systematic review and meta-analysis
}

\author{
Amanda Roberts $P h D^{1 *}$, Jim Rogers $P h D^{2}$, Stephen Sharman $P h D^{3}$, G.J. Melendez-Torres \\ $P h D^{4}$, Sean Cowlishaw $P h D^{5,6}$
}

${ }^{1}$ School of Psychology, College of Social Science, University of Lincoln, Brayford Pool, Lincoln, Lincolnshire. LN6 7TS, UK

${ }^{2}$ School of Health and Social Care, College of Social Science, University of Lincoln, Brayford Pool, Lincoln, Lincolnshire. LN6 7TS, UK

${ }^{3}$ National Addictions Centre, Kings College London, 4 Windsor Walk, Camberwell, London SE5 8AF, UK

${ }^{4}$ Peninsula Technology Assessment Group, College of Medicine and Health, University of Exeter, Heavitree Road, Exeter, EX1 2LU, UK

${ }^{5}$ Department of Psychiatry, University of Melbourne, Carlton VIC 3053, AUSTRALIA

${ }^{6}$ Population Health Sciences, Bristol Medical School, University of Bristol, Bristol. BS8 2PS, UK

\section{* Corresponding author:}

Dr Amanda Roberts School of Psychology, College of Social Science, University of Lincoln, Brayford Pool, Lincoln, Lincolnshire. LN6 7TS, UK: aroberts@lincoln.ac.uk

Tel: +44 (0) 1522886190

Amanda Roberts ORCID identifier: 0000-0002-2889-9551 


\begin{abstract}
Aims

To synthesise evidence regarding gambling problems in primary care contexts as evidence suggests that problem gambling may be overrepresented. Objectives were to review all the available evidence regarding the frequency and implications of gambling problems in primary care. The latter were operationalised by covariates relating to physical and mental health that suggest clinical implications, as well as co-occurring addictive behaviours.
\end{abstract}

\title{
Methods
}

Peer reviewed articles published in MEDLINE, Embase, PsycINFO, CINAHL and Sociological Abstracts reporting data relating to gambling and associated problems were screened. Where possible, random effects meta-analysis was used to combine study estimates.

\section{Findings}

The search identified 14 articles (based on 11 individual studies) from 1708 deduplicated records. Meta-analyses of data from 10 studies indicated around $3.0 \%$ of patients reported significant levels of problem gambling, although there was substantial heterogeneity and rates ranged from around $1 \%$ to $15 \%$ across studies. In contrast, there were few studies reporting findings relating to gambling problems across a broader continuum of severity, and there is little known about sub-clinical problems (i.e., at-risk gambling) in primary care. There was generally consistent evidence of links between problem gambling and poor mental health and co-occurring substance use problems. In contrast, there was less evidence regarding the physical health implications of problem gambling in primary care.

\section{Conclusions}

Primary care may provide an important environment for the detection of gambling problems and should identify patients reporting gambling problems across a continuum, consistent with principles of case finding; thereby targeting investigation on those suspected to be 'at risk'.

Keywords: Primary Care, Gambling, Problem Gambling, At-risk Gambling, Systematic review, mental health 


\section{INTRODUCTION}

Recent epidemiological evidence indicates that $54 \%$ of individuals aged $16+$ report gambling annually in the UK (Health Survey England (HSE), 2018), with similar comparable figures from other international jurisdictions including Australia (Armstrong, Thomas, \& Abbott, 2018), the U.S. (Tracy, Maranda, \& Scheele, 2018), and Europe (Salonen, Hellman, Latvala, \& Castrén, 2018). Gambling can sometimes escalate to problematic levels characterised by persistent and recurrent maladaptive behaviour that leads to significant personal and social harms (Hodgins, Stea, \& Grant, 2011). Although rates of gambling disorders are commonly below $1 \%$, there are larger numbers reporting at-risk gambling (around $6 \%$ and $2 \%$ of men and women, respectively; HSE, 2018); defined by experiences of at least some problems or adverse consequences from gambling (although often below levels required for a gambling disorder) and vulnerability to future disorders.

The terminology used with reference to gambling is variable; terms such as 'problem', 'pathological', and 'disordered' gambling are often used interchangeably. Gambling was re-classified from an impulse control disorder to an addiction in the most recent version of the Diagnostic and Statistical Manual of Mental Disorders, and renamed 'gambling disorder' (American Psychiatric Association, 2013). In contrast, the term 'problem gambling' is more closely aligned with a public heath perspective and is often used to describe clinically significant forms of gambling that lead to serious negative consequences (Cowlishaw et al, 2019). The term 'problem gambling' will thus be used hereafter to describe people who experience any clinically significantly gambling-related condition (including gambling disorder), while the term 'at-risk gambling' will be used to reference less severe or subclinical conditions, consistent with prior research (Cowlishaw at al., 2020; Cowlishaw, Gale, Gregory, McCambridge, \& Kessler, 2017).

There is growing recognition of the adverse consequences of gambling, which may comprise vocational disruptions (e.g., job loss; Langham et al., 2015), deviant and criminal behaviour (Roberts, Sharman, King, Bayston, \& Bowden-Jones, 2019), as well as severe financial problems (Grant, Schreiber, Odlaug, \& Kim, 2010), mental health issues (Krause et al., 2018), and interpersonal difficulties (Roberts et al., 2018). The increasing awareness of the magnitude of these issues has provided impetus for initiatives to reduce maladaptive gambling and associated harms (Public Health England, 2020). These initiatives may include programs of intensive treatment that have been shown to reduce excessive gambling behaviour in the short-term (Cowlishaw et al., 2012). However, problem gambling is characterised generally by low levels of help-seeking (around $90 \%$ of people with gambling problems never access services; Cunningham, 2005), which is typically 'crisis driven' (Evans \& 
Delfabbro, 2005), and thus occurs only after experiencing severe harm (e.g., bankruptcy, relationship breakdown). As such, there is a strong need for early intervention or secondary prevention initiatives that can address excessive behaviour or subclinical problems before they progress to chronic forms of problem gambling.

Primary care is an important context for early identification and intervention with a range of high-risk behaviours, including alcohol (Kaner et al., 2009) and illicit drug use (Pilowsky \& Wu, 2012). Furthermore, it has been suggested that primary care may provide an equivalent context for early intervention with at-risk and problem gambling (Griffiths, 2007). Recently, it was suggested that GPs should screen high risk groups (e.g., patients with financial problems) and refer positive cases for assessment and specialist treatment (Roberts, Bowden-Jones, Roberts, \& Sharman, 2019; Sanju \& Gerada, 2011). This is in line with evidence that problem gambling co-occurs frequently with other health complaints (Goodyear-Smith et al., 2006) and may be overrepresented in primary care (Levens, Dyer, Zubritsky, Knott, \& Oslin, 2005; Morasco, Vom Eigen, \& Petry, 2006; Pasternak \& Fleming, 1999). In a recent study using population-based data, individuals with gambling problems were shown to be twice as likely to consult their GP, and five times as likely to be hospital inpatients, when compared to individuals with no gambling problems (Cowlishaw \& Kessler, 2016). Common comorbidities with problem gambling include substance use and mood disorders (Lorains, Cowlishaw, \& Thomas, 2011), that are presumed to reflect complex underlying mechanisms including shared underlying vulnerabilities and reciprocal processes that unfold over time (Sundqvist, \& Rosendahl, 2019; Hartmann \& Blaszczynski, 2018). Furthermore, there are additional associations with health complaints including obesity, hypertension, intestinal distress and headaches (Black, Shaw, McCormick, \& Allen, 2013). Notwithstanding, it seems that gambling continues to receive limited attention in the context of health care systems and remains low on the list of priorities for funding for treatment or prevention services (Rigbye \& Griffiths, 2011; The Lancet, 2017).

The UK's National Screening Committee (NSC), which is part of Public Health England, have outlined criteria for appraising the appropriateness of screening for health-related problems and conditions, and foremost among these is the requirement that problems are deemed 'important', as judged by evidence of both (a) frequency and (b) severity (Public Health England, 2015). This is commonly operationalised in terms of evidence regarding (a) prevalence and (b) implications for health, the latter including studies of associations with important health-related outcomes (Feder et al., 2009; National Collaborating Centre for Mental Health, 2011). In line with this, the current paper presents a 
systematic review of all available evidence regarding the frequency and implications ('severity' as defined above by the NSC) of gambling problems in primary care; the latter operationalised by covariates relating to physical and mental health that suggest clinical implications, as well as cooccurring addictive behaviours. Specific objectives are to:

(a) Provide best available estimates of the prevalence of at-risk and problem gambling in primary care; and

(b) Review existing evidence regarding the implications of gambling problems in primary care, as indicated by links with physical and mental health problems, as well as co-occurring addictive behaviours.

\section{METHODS}

Our review is compliant with the Preferred Reporting Items for Systematic Reviews and Meta-Analyses (PRISMA; Liberati et al., 2009). The protocol for this systematic review was registered with PROSPERO (ID: CRD42018112847). There were no deviations from the pre-registration.

\section{Search Strategy}

Our search was conducted in July 2019. Electronic searches of academic databases (MEDLINE, Embase, PsycINFO, CINAHL, Sociological Abstracts) were conducted using a combination of keywords relating to gambling and primary care (see the appendix for search terms). Our search was restricted to articles published in peer-reviewed journals, with no restriction on publication period.

\section{Inclusion and Exclusion Criteria}

We required that studies considered patients of primary care services. For purpose of this review, primary care settings were defined as services providing first contact and ongoing care for patients demonstrating all types of health problems, and mainly comprised general or family practice settings. Services not considered included ambulatory care and accident and emergency.

We also required that studies reported data relating to at-risk or problem gambling and included studies of patients reporting data on brief screens or individual questions for gambling problems, as well as studies of problem gambling identified using longer assessment tools. The former includes questionnaires such as the Lie/Bet Questionnaire; Johnson et al., 1997), and the NODS-CLiP (The National Opinion Research Center DSM Screen for Gambling Problems (NODS) Control, Lying and 
Preoccupation Measure; Toce-Gerstein, Gerstein, \& Volberg, 2009), which all comprise five items or less. Longer scales include questionnaires such as the South Oaks Gambling Screen (SOGS; Lesieur \& Blume, 1987) and Problem Gambling Severity Index (PGSI; Ferris \& Wynne, 2001). We also recorded if there were any links involving at-risk or problem gambling and physical and mental health problems, including addictive behaviours, although this was not a requirement. We adopted an inclusive approach to the definition and measurement of these additional problems, individual questions, brief or longer assessment tools.

Our review only included studies where primary care patients (age $\geq 16$, any gender) were considered and included experimental studies, controlled trials, cohort studies, case series reports, and qualitative studies. We excluded studies if they failed to report findings relating to gambling problems, did not report empirical data, described data from samples drawn primarily from non-primary care settings (such as dental practices), included participants under the age of 16 or were not published in English. Where there was insufficient information to make a judgement on the eligibility criteria, we excluded the study from the review.

\section{Data Extraction}

We extracted data on descriptive features of studies, including year of publication, sample characteristics, response rate, setting and if the latter included disadvantaged populations serviced by primary care practices. Additional characteristics included recruitment strategy and methods of measurement of problem/at-risk gambling. Where relevant, we also extracted data on (a) the proportion/number of patients reporting gambling problems (prevalence), and (b) the results of any tests of association involving gambling problems and physical/mental health comorbidities. Two primary members of the study team independently screened articles by abstract and title based on the above criteria. Articles were then independently read in full by the same reviewers and included or excluded based on the same criteria and on a quantitative assessment of methodological quality using the Joanna Briggs Institute Critical Appraisal Checklist for Studies Reporting Prevalence Data (Munn, Moola, Lisy, Riitano, \& Tufanaru, 2015). Disagreements regarding the inclusion of papers were resolved through discussion and there was no unresolved conflict. The interrater agreement for across the two primary reviewers was $100 \%$.

\section{Data syntheses}

There were different approaches adopted to the syntheses of data regarding objective (a) and (b), respectively, given variable characteristics of information reported. To address objective (a), random 
effects meta-analyses were used to synthesise data from all available studies regarding prevalence of at-risk and problem gambling in primary care. These analyses were conducted in R using the 'metaprop' function from the 'meta' package. The $I^{2}$ statistic was produced to quantify the amount of between-study variation beyond chance alone (Higgins, Thompson, Deeks, \& Altman, 2003). Data from studies providing estimates of problem gambling using brief screens and longer scales were both considered (data from longer scales were utilised when figures from both measures were reported), with meta-regressions conducted to compare findings from longer scales (e.g SOGS) versus brief screens (e.g. NODS-CLIP), as well as according to decade (pre-2010 versus post-2010) and jurisdiction (North America vs. International). There was less consistent data from studies regarding the covariates of gambling problems, and it was not possible to conduct meta-analyses of quantitative findings to address objective (b). These findings from primary studies were instead synthesised narratively.

\section{RESULTS}

\section{Search results}

Once duplicate records were removed, the search produced 1708 citations. Titles and abstracts were reviewed for eligibility and yielded an initial pool of 29 articles for which full text was examined. This pool included studies that were not relevant to the review, including those that did not report empirical data (Goodyear-Smith, Warren, \& Elley, 2013; Sullivan, 2007), or reported data on samples comprising employees of primary care settings (Chithiramohan \& George, 2016; Petry \& Mallya, 2004; Tolchard, Thomas, \& Battersby, 2007), included participants recruited from other medical services such as dental practices (Petry, 2006) or participants under the age of 16 (Calveley, Verhoeven, \& Hopcroft, 2009). Excluding these left 11 individual studies reported across 14 articles. See Figure 1 for PRISMA flow diagram of search results.

\section{Figure 1}

\section{Characteristics of studies}

Characteristics of included studies are shown in Table 1. All studies were quantitative and involved samples of primary care patients, which ranged in size from $n=265$ to $n=2543$. Patients ranged widely in age with the youngest participants being 16 years, and another study of older adults (65+ years) where the mean age was 74.1 years. Where reported, the percentage of female participants ranged from $30 \%$ to $75 \%$, and the response rates ranged from $59 \%$ to $98 \%$. The majority of studies reported data from disadvantaged populations serviced by primary care practices (7). Specifically; Cowlishaw et al., (2017) Included four practices (out of 11) from the top $30 \%$ deprived areas in 
England; Elley et al., (2014) included one inner-city health centre providing primary care for adults without medical coverage in British Columbia, Canada; Goodyear-Smith et al. (2008; 2009; 2013) included practices in socioeconomically deprived areas in South Auckland, New Zealand; Morasco, vom Eigen, \& Petry (2006) recruited from an urban primary care practice which served a low-income population in Connecticut, USA; and Pastenak and Fleming (1999) included one clinic in in a lowincome area of Madison, USA.

Table 1

Six studies measured problem gambling using longer measurement tools, including the SOGS (Lesieur \& Blume, 1987) (4), PGSI (Ferris \& Wynne, 2001) (1), and the 8-item Early Intervention Gambling Health Test (EIGHT Screen; Sullivan, 2007) (1) (see table 1). Studies that administered the SOGS originated in the U.S. (Morasco et al., 2006; Pasternak \& Fleming, 1999) and New Zealand (GoodyearSmith et al., 2008; Goodyear-Smith, Arroll, \& Coupe, 2009), and reported data according to multiple cut-offs for severity of gambling problems which typically extended from 3-4 (problem gambling) and $5+$ (probable pathological gambling).

Table 1 indicates 8 studies that reported rates of gambling problems identified using brief screens. Studies conducted in New Zealand (Goodyear-Smith et al., 2006; 2008; 2009) and Canada (Elley et al., 2014), administered one ${ }^{1}$ or two items from the 'Case-finding and Help Assessment Tool' (CHAT; Goodyear-Smith et al., 2008), including the electronic version (e-CHAT; Goodyear-Smith, Warren, Bojic, \& Chong, 2013), or the Multi-item Short Screening tool (MIST; Goodyear-Smith et al., 2004). These items were presented alongside additional questions regarding behaviours and conditions including smoking, alcohol, substance abuse, depression, anxiety, stress, violence, eating disorders and physical activity. One U.S. study (Levens et al., 2005) administered two items derived from the SOGS to older adults (aged 65+ years) defined by gambling more than $\$ 100$ on a single bet, and/or betting more than they could afford to lose. One UK study (Cowlishaw, McCambridge, \& Kessler, 2018) administered the NODS-CLIP (Toce-Gerstein et al., 2009), and one study from Sweden (Nehlin, Nyberg, \& Jess, 2016) administered the NODS-PERC (The NODS Preoccupation, Escape, Chasing and Risked Relationships Measure; Volberg, Munck, \& Petry, 2011).

\section{Prevalence of gambling problems}

\footnotetext{
${ }^{1}$ This single item comprised the earlier version of this tool, sometimes referred to as the multi-item short screening tool (MIST; Goodyear-Smith at el., 2004).
} 
Table 2 summarises results from included studies regarding rates of both at-risk and problem gambling in primary care. As can be seen, there were only two studies that reported figures relating to gambling problems across a continuum of severity, including at-risk gambling. One UK study identified $4.3 \%$ of patients that were at-risk gamblers, and $5.2 \%$ that reported any gambling problems across a continuum of severity (including at-risk and problem gambling) using the PGSI (Cowlishaw et al., 2017). The second study identified $10.9 \%$ of older adult patients (aged 65+ years) that reported gambling more than $\$ 100$ on a single bet, and/or betting more than they could afford to lose (Levens et al., 2005). In contrast, there were 10 studies that reporting rates of problem gambling and these ranged from $0.7 \%$ to $15.7 \%$ across studies (see Figure 1 ). Syntheses of these figures via random effects metaanalyses produced a weighted mean estimate of $3.0 \%(95 \% \mathrm{Cl}=1.6 \%$ to $5.6 \%)$.

\section{Table 2}

The $1^{2}$ statistic from the aforementioned meta-analysis (see Table 2) demonstrated high levels of statistical heterogeneity across studies, and suggested that while the weighted mean provided an appropriate overall estimate of the prevalence of problem gambling in primary care across studies, there were also potential contexts in which conditions might be more versus less common. As such, subgroup analyses using random effects models were also conducted to examine factors explaining this variability in prevalence, and considered (a) length of gambling measurement (brief screen versus extended measure), (b) decade of publication (pre-2010 versus post-2010) and (b) international jurisdiction (North America versus Other). Results of these analyses are displayed in Table 3. Although findings should be interpreted cautiously in the light of the small number of studies, the $95 \% \mathrm{Cls}$ for sub-group mean estimates were overlapping, and thus indicated no significant differences according to these study characteristics.

\section{Table 3}

\section{Narrative synthesis: Implications of gambling problems}

The included studies reported heterogeneous methodology regarding the covariates of gambling problems, which were generally unsuitable for quantitative syntheses via meta-analyses. As such, the relevant findings regarding associations with physical and mental health measures, as well as cooccurring addictive behaviours, were synthesised narratively. In previous sections, the term problem gambling has been used to refer to clinically significant gambling-related conditions (including gambling disorder), while at-risk gambling has been used to refer to subclinical conditions. However, for purposes of this narrative synthesis we have reported the terminology and specific operational definitions (e.g. SOGS $3+$ ) used in the original studies. 


\section{Physical health}

There were 4 studies that reported on the physical health covariates of gambling problems in primary care, and these demonstrated mixed findings. Morasco et al., (2006) considered associations with physical health subscales from the Short-Form Health Survey, Version 2 (SF-12v2; Ware, Kosinski, \& Keller, 1996), and reported that both problem gamblers (SOGS 3-4) and pathological gamblers (SOGS $5+)$ performed worse, relative to non-gamblers and recreational gamblers. This included worse scores on indices of role-physical (limitations due to physical problems), bodily pain and general health. Pasternak \& Fleming (1999) considered items from the Short Form 36 (SF-36; Jenkinson, Coulter, \& Wright, 1993) and found that problem gamblers (SOGS 3+) rated their health more poorly and reported more severe symptoms of heartburn and backache. In contrast, there were no differences between patients who exhibited problem gambling (SOGS $3+$ ) and non-problem gamblers in terms of self-reports of conditions including headache and impotence. Levens et al., (2005) also found no discernible differences on self-rated health (MOS SF-36: MOS 36-item Short-Form Health Survey; McHorney, Ware Jr, Lu, \& Sherbourne, 1994) across problem gambling categories, while GoodyearSmith et al., (2006) reported that patients reporting concerns with gambling were no more likely to report concurrent concerns relating to weight or physical activity.

\section{Mental health}

There were 6 studies that evaluated mental health implications of gambling problems in primary care, and these generally demonstrated associations between gambling and mental health problems. One study demonstrated links with mental health subscales from the SF-12v2 (Ware et al., 1996). Morasco and colleagues (2006) found that both problem gamblers (SOGS 3-4) and probable pathological gamblers (SOGS 5+) performed worse, relative to non-gamblers and recreational gamblers, according to general mental health component scores, as well as sub-dimensions of social functioning and roleemotional (limitations due to emotional problems). Other studies considered mental health covariates comprising self-report measures of specific mental health conditions. Pasternak \& Fleming (1999) found that problem gamblers (SOGS $3+$ ) exhibited increased risk of positively endorsing items reflecting anxiety and depression. Goodyear-Smith et al., (2006) also found that patients reporting concerns with gambling were almost three times more likely to report depression, over two times more likely to report anxiety, and two and a half times more likely to report anger, relative patients who reported no such concerns. Sullivan, McCormick, Lamont, \& Penfold, (2007) found that problem gamblers (EIGHT Screen 4+) had a more than a twofold increase in the risk of screening positive to depression (two-item measure; Whooley, Avins, Miranda, \& Browner, 1997) compared to non- 
problem gamblers. Likewise, Cowlishaw et al., (2017) found that patients screening positive for depression demonstrated a twofold increase in rates of gambling problems (PGSI 1+), while Levens and colleagues, (2005) found that at-risk gamblers demonstrated near threefold increases in the risk of post-traumatic stress disorder using a brief scale when compared to non-gamblers and recreational gamblers.

There were some studies that failed to identify discernible links with gambling problems and specific mental health problems. Cowlishaw et al., (2017) found no significant association between gambling problems and the likelihood of screening positive for anxiety on the Generalized Anxiety Disorder 2-item (GAD-2; Kroenke, Spitzer, Williams, Monahan, \& Löwe, 2007), while Levens et al., (2005) found no clear links across problem gambling categories with the likelihood of depression (as measured by the General Health Questionnaire: GHQ; Jackson, 2007), suicidal ideation (Primary Care Evaluation of Mental Disorders: PRIME-MD; Spitzer et al., 1994) or cognitive impairment (Brief Orientation Memory Concentration Test: BOMC; Blessed, Tomlinson, \& Roth, 1968).

\section{Addictive behaviours}

There were 4 studies that reported associations with gambling problems and other addictive behaviours. Pasternak \& Fleming (1999) found that problem gamblers (SOGS 3+) had more than a threefold risk of recent tobacco use and more than a twofold risk of alcohol abuse (CAGE; Ewing, 1984), relative to non-gamblers and non-problem gamblers. There were additional associations with number of drinks per day. While no relation was observed between any marijuana use in the past 6 months, there was a marginally significant $(p=0.06)$ trend towards increased risk of developing a gambling disorder among patients who reported higher marijuana lifetime use. Goodyear-Smith et al., (2006) found that concerns with gambling were associated with near four-fold increases in reporting concerns relating to smoking, five-fold increases in reported concerns with drug use, almost threefold increases in concerns with alcohol use. Likewise, Cowlishaw et al., (2017) found that alcohol use (Alcohol Use Disorders Identification Test: AUDIT-C; Bradley et al., 2007) was associated with a near threefold increase in gambling problems (PGSI 1+), while a single item screening measure for unhealthy drug use (SISQ; McNeely et al., 2015) was associated with a fivefold increase in gambling problems. Levens et al., (2005) found that at-risk gamblers demonstrated a near sixfold increase in binge drinking compared to non-gamblers. Recreational gamblers had more than a fourfold increase in binge drinking compared to non-gamblers. Conversely, this study indicated no clear evidence of meaningful differences according to smoking status or at-risk alcohol use. 


\section{Quality Assessment}

The majority of studies utilized an adequate sample size $(81.8 \%, 9)$; two studies that did not have a large sample size were feasibility studies. Most articles also had an adequate response rate $(81.8 \%$, 9); we were unable to access this criterion in two studies as they did not report response rate details. All other criteria were fulfilled in $100 \%$ (11) of the studies and no studies were removed. As far as we are aware, none of the studies followed open sciences practices (e.g. were pre-registered).

\section{DISCUSSION}

This review identified modest evidence regarding gambling problems in primary care, which comprised 11 studies that were mainly from New Zealand and the U.S. Meta-analyses of data from 10 studies indicated around $3.0 \%$ of patients reported significant levels of problem gambling, although there was substantial heterogeneity and rates ranged from around $1 \%$ to $15 \%$ across studies. In contrast, there were few studies reporting findings relating to gambling problems across a broader continuum, and there is little known about sub-clinical problems in primary care. The review also identified preliminary evidence regarding implications of problem gambling in this health service environment, and narrative syntheses indicated that there was generally consistent evidence of links with poor mental health and co-occurring substance use problems. In contrast, there was less evidence regarding the physical health implications of problem gambling in primary care, while findings from included studies were inconsistent and thus inconclusive.

\section{Comparison with existing literature}

The modest number of published studies in this review is dwarfed by comparable literature regarding alcohol use problems (e.g. Dzidowska et al., 2020), and is small relative to nascent evidence regarding other mental health problems in primary care (e.g., PTSD; Greene, Neria, \& Gross, 2016). In the context of modest numbers of published studies, the existing literature provides only preliminary evidence regarding the frequency of gambling problems in primary care. However, the quantitative syntheses of available studies suggested around $3.0 \%$ of primary care patients exhibit significant gamblingrelated conditions that may be characterised in terms of problem gambling. By way of comparison, recent studies of primary care have suggested around $12 \%$ of patients exhibit alcohol use disorders (Manthey et al., 2016), and around 14\% demonstrate PTSD (Spoont et al., 2015). Thus, it seems that rates of problem gambling are low relative to disorders that have greater traditions of recognition in primary care. 
However, it is important to acknowledge that the current analyses also identified high levels of unexplained statistical heterogeneity across studies, and this may suggest environments in which gambling problems are more versus less common. The availability and distribution of gambling varies considerably across countries and may account in part for discrepant prevalence rates across studies. Moreover, the characteristics of populations that are serviced by primary care practices could also explain some between-study heterogeneity in estimates and the particularly high rates of gambling problems in some studies. By way of example, previous research has indicated that gambling problems may be more common in areas characterised by high socio-economic disadvantage (see Sharman et al., 2019), and it may be expected that higher rates of problem gambling would also be found in primary care practices in socio-economically disadvantaged locations. Furthermore, publicly funded universal health care systems, such as the National Health Service (NHS) in the UK, contribute towards reduced socioeconomic disparities in access to medical services, which may ultimately increase rates of gambling problems in primary care in these countries, and particularly in disadvantaged areas (Asaria et al., 2016; Cookson et al., 2017). In contrast, economic and health inequalities may be amplified in countries without universal healthcare (Dickman, Himmelstein, \& Woolhandler, 2017), such that recorded rates of problem gambling may be lower because deprived groups have reduced access to services.

The current review identified only one study that reported rates of at-risk gambling (Cowlishaw et al., 2017), and this suggested that these sub-clinical cases were more prevalent than problem gambling by a factor of almost five. This latter finding is consistent with broader literature arguing that rates of problem gambling prevalence heavily underestimate the magnitude of harm from gambling (Markham, Young, \& Doran, 2016; Young, 2013). Recent studies also suggest that sub-clinical problems may account for large proportion of the burden of gambling at the population level (Browne, Greer, Rawat, \& Rockloff, 2017), and should be major targets of intervention strategies. The marked absence of evidence regarding at-risk gambling is particularly striking in primary care, where there is a predominant focus on high-risk behaviours and low-severity problems (Saitz, 2010) that are also indicated targets of low-intensity interventions and secondary prevention strategies that aim to avoid harms and negative consequences before they occur.

The review identified a small number of studies that provided informative data regarding links with problem gambling and health-related measures, and these suggested that the most consistent 
associations were with indicators of poor mental health, as well as co-occurring addictive behaviours. The relevant evidence was heterogeneous in terms of measures that were associated with problem gambling, and these included non-specific mental health and functioning scales, such as the SF-36 (Jenkinson et al., 1993), as well as brief measures of conditions including depression and anxiety. Such differences precluded the quantitative synthesis of findings via meta-analysis, and it remains unclear whether associations varied meaningfully across studies, and whether this was due to substantive differences, or alternatively, could be attributed to sampling error alone. However, the findings are aligned with literature which indicates that problem gambling is strongly associated with other dimensions of mental health and addiction (Cowlishaw \& Kessler, 2016), and co-occurs frequently with mood, anxiety, and substance use disorders (Lorains et al., 2011). Although mechanisms which underlie these associations are expected to be complex, it is likely that gambling and other disorders could originate from shared vulnerabilities but are maintained through reciprocal processes which unfold over time (e.g. similar neurobiological processes; Potenza, 2013). For example, it seems likely that gambling losses and debts may have impacts on mental health, while distress or negative mood states associated with psychiatric problems might also precipitate gambling as a way of decreasing negative affect (Morasco, Weinstock, Ledgerwood, \& Petry, 2007).

The current review identified less evidence regarding links involving gambling problems and physical health, when compared to links with gambling problems and mental health, while the available studies were equivocal about these potential implications of gambling problems in primary care. There were general trends suggesting that increasing severity of problem gambling was associated with worse physical health. Previous studies in the general population have found that problem gambling is associated with poor health (e.g. Afifi, Cox, Martens, Sareen, \& Enns, 2010). The relationship between physical health and gambling is abstruse. It has been suggested that spending time on a sedentary activity such as gambling may impede physical health, or that those who have poor health are more likely to drawn to such activities (Erickson et al., 2005). However, despite the links, gambling problems are seldom discussed in the same context as other issues in primary care settings, due perhaps to a perception that it is a less serious issue (Roberts et al., 2019). Knowledge of which symptoms to look out for could help primary care providers to better identify gambling problems among their patients in practice.

\section{Limitations}


The degree of heterogeneity across studies is difficult to interpret and consequently, a meta-analysis for the health covariates was not possible. The heterogeneity may partly reflect differences across national contexts, which could be attributable to variability in the population prevalence of problem gambling, as well as heterogeneity across healthcare services and gambling environments. This heterogeneity may also reflect different measurement strategies, including reliance on brief screening tools and longer self-report measures, which adopted different definitions of gambling-related conditions (e.g., gambling disorder, pathological or problem gambling) and arbitrary thresholds for distinguishing across levels of gambling problem severity. In addition, publication bias is a problem; null associations less likely to be published (Easterbrook, Gopalan, Berlin, \& Matthews, 1991). The latter may be alleviated in some way in the future by increased use of open science practices, including pre-registration, registered reports and replications (Heirene, 2020; Louderback, Wohl, \& LaPlante, 2020).

\section{Implications}

Findings of preliminary studies suggest that primary care may provide an important environment for the identification and response to gambling problems. However, notwithstanding the reasons to suggest that gambling problems are important considerations, there seems to be a general dearth of relevant research. Lacking evidence, it may be assumed that some recommendations for managing problematic alcohol use could be generalised in part to initiatives for maladaptive gambling. Alcohol and gambling are similar in the sense that both are legal products with addictive potential and may lead to disorders that share features including loss of control, tolerance and withdrawal, and significant personal or social consequences (Hodgins et al., 2011). There is also evidence that similar approaches to intervention can reduce both alcohol (National Collaborating Centre for Mental Health (NCCMH), 2011) and gambling problems (Cowlishaw et al., 2012), and these commonly include components of motivational interviewing and cognitive-behavioural therapy (Hodgins et al., 2011; NCCMH, 2011).

Invariably, there will be unique challenges to relevant interventions for gambling problems. Gambling may be easier to conceal than alcohol use (given the lack of a physiological dependence), while patients may be less likely to disclose gambling as a source of difficulties (e.g., due to stigma; Hing, Holdsworth, Tiyce, \& Breen, 2014; Roberts et al., 2019). Alcohol use and harm is generally far more pronounced with rates of service usage by hazardous and harmful drinkers as high as $20-30 \%$ in primary care (Coulton et al., 2017) which suggests a much greater yield from identification strategies. 
There are also clear physical health risks of alcohol (Rehm, 2011), which may be less obvious in people with gambling problems. Instead, individuals with gambling problems are more likely to have comorbid mental health disorders and psychosocial problems that may be less visible to primary care providers. Given the speculation that problem gambling is not necessarily viewed as a bona fide mental health problem in health services (Roberts et al., 2019), this ambivalence may represent additional obstacles to new initiatives.

If primary care providers are to identify gambling problems, there needs to be a suitable method of doing so. In routine practice, primary care providers are effective at identifying physical and other mental health problems. Our findings may suggest that primary care providers should identify people with gambling problems by "case finding"; recognizing individuals who are suspected to be at risk of problem gambling (i.e. have any related symptoms) for further investigation. Thereafter, there should be a simple, precise screening test. All the studies in this review utilised measures designed to detect problem gambling as a clinically significant condition. However, gambling problems are considered to exist on a continuum of severity and include those with subclinical problems who are at-risk of problem gambling (Cowlishaw et al., 2019). Current screens are designed to measure problem gambling at the severe end of this continuum and do not necessarily detect low severity issues. There is a compelling need for the development of new screens that can detect subclinical problems and secondary prevention initiatives that then address them before they progress to severe and chronic forms of gambling disorder. Problem and at-risk gambling should receive increased attention in health care systems and rise up the list of priorities for funding for treatment or prevention services.

Disclosure of Interest: The authors report no conflicts of interest. The conduct of this current project was unfunded.

\section{References}

Afifi, T. O., Cox, B. J., Martens, P. J., Sareen, J., \& Enns, M. W. (2010). The relationship between problem gambling and mental and physical health correlates among a nationally representative sample of Canadian women. Canadian Journal of Public Health, 101(2), 171175. 
American Psychiatric Association (2013). Diagnostic and Statistical Manual of Mental Disorders, 5th ed. Washington DC: American Psychiatric Association.

Armstrong, A. R., Thomas, A., \& Abbott, M. (2018). Gambling participation, expenditure and risk of harm in Australia, 1997-1998 and 2010-2011. Journal of Gambling Studies, 34(1), 255-274.

Asaria, M., Ali, S., Doran, T., Ferguson, B., Fleetcroft, R., Goddard, M., Goldblatt, P., Laudicella, M., Raine, R., \& Cookson, R. (2016). How a universal health system reduces inequalities: Lessons from England. Journal of Epidemiology and Community Health, 70(7), 637-643.

Black, D. W., Shaw, M., McCormick, B., \& Allen, J. (2013). Pathological gambling: relationship to obesity, self-reported chronic medical conditions, poor lifestyle choices, and impaired quality of life. Comprehensive Psychiatry, 54(2), 97-104.

Blessed, G., Tomlinson, B. E., \& Roth, M. (1968). The association between quantitative measures of dementia and of senile change in the cerebral grey matter of elderly subjects. The British Journal of Psychiatry, 114(512), 797-811.

Bradley, K. A., DeBenedetti, A. F., Volk, R. J., Williams, E. C., Frank, D., \& Kivlahan, D. R. (2007). AUDIT-C as a brief screen for alcohol misuse in primary care. Alcoholism: Clinical and Experimental Research, 31(7), 1208-1217.

Browne, M., Greer, N., Rawat, V., \& Rockloff, M. (2017). A population-level metric for gamblingrelated harm. International Gambling Studies, 17(2), 163-175.

Calveley, J., Verhoeven, A., \& Hopcroft, D. (2009). A patient-centred referral pathway for mild to moderate lifestyle and mental health problems: Does this model work in practice? Journal of Primary Health Care, 1(1), 50-56.

Chithiramohan, T. N., \& George, S. (2016). Gambling addiction in primary care: a survey of general practitioners in Solihull. Internet Journal of Medical Update, 11(2), 2-6.

Cookson, R., Mondor, L., Asaria, M., Kringos, D. S., Klazinga, N. S., \& Wodchis, W. P. (2017). Primary care and health inequality: difference-in-difference study comparing England and Ontario. Plos One, 12(11), e0188560. 
Coulton, S., Drummond, C., Deluca, P., Kaner, E., Newbury-Birch, D., Perryman, K., \& Phillips, T. (2012). The utility of different screening methods to detect hazardous drinking and alcohol use disorders in the Screening and Intervention Program for Sensible Drinking (SIPS) program. In Addiction Science \& Clinical Practice (Vol. 7, No. 1, pp. 1-1). BioMed Central.

Cowlishaw, S., Metcalf, O., Lawrence-Wood, E., Little, J., Sbisa, A., Deans, C., O'Donnell, M., Sadler, N., Van Hooff, M., Crozier, M., \& Battersby, M. (2020). Gambling problems among military personnel after deployment. Journal of Psychiatric Research, 131, 47-53.

Cowlishaw, S., Gale, L., Gregory, A., McCambridge, J., \& Kessler, D. (2017). Gambling problems among patients in primary care: a cross-sectional study of general practices. British Journal of General Practice, 67(657), e274-e279.

Cowlishaw, S., Merkouris, S. S., Dowling, N. A., Rodda, S., Suomi, A., \& Thomas, S. L. (2019). Locating gambling problems across a continuum of severity: Rasch analysis of the Quinte Longitudinal Study (QLS). Addictive Behaviors, 92, 32-37.Cowlishaw, S., \& Kessler, D. (2016). Problem gambling in the UK: Implications for health, psychosocial adjustment and health care utilization. European Addiction Research, 22(2), 90-98.

Cowlishaw, S., McCambridge, J., \& Kessler, D. (2018). Identification of gambling problems in primary care: properties of the NODS-CLiP screening tool. Journal of Addiction Medicine, 12(6), 442446.

Cowlishaw, S., Merkouris, S., Dowling, N., Anderson, C., Jackson, A., \& Thomas, S. (2012). Psychological therapies for pathological and problem gambling. Cochrane Database of Systematic Reviews, (11).

Cunningham, J. A. (2005). Little Use of Treatment Among Problem Gamblers. Psychiatric Services, 56(8), 1024-a-1025.

Dickman, S. L., Himmelstein, D. U., \& Woolhandler, S. (2017). Inequality and the health-care system in the USA. The Lancet, 389(10077), 1431-1441. 
Dzidowska, M., Lee, K. K., Wylie, C., Bailie, J., Percival, N., Conigrave, J. H., ... \& Conigrave, K. M. (2020). A systematic review of approaches to improve practice, detection and treatment of unhealthy alcohol use in primary health care: a role for continuous quality improvement. BMC Family Practice, 21(1), 1-22.

Elley, C. R., Dawes, D., Dawes, M., Price, M., Draper, H., \& Goodyear-Smith, F. (2014). Screening for lifestyle and mental health risk factors in the waiting room: feasibility study of the Casefinding Health Assessment Tool. Canadian Family Physician, 60(11), e527-e534.

Erickson, L., Molina, C. A., Ladd, G. T., Pietrzak, R. H., \& Petry, N. M. (2005). Problem and pathological gambling are associated with poorer mental and physical health in older adults. International Journal of Geriatric Psychiatry, 20(8), 754-759.

Evans, L., \& Delfabbro, P. H. (2005). Motivators for change and barriers to help-seeking in Australian problem gamblers. Journal of Gambling Studies, 21(2), 133-155.

Ewing, J. A. (1984). Detecting alcoholism: the CAGE questionnaire. Jama, 252(14), 1905-1907.

Feder, G., Ramsay, J., Dunne, D., Rose, M., Arsene, C., Norman, R., Kuntze, S., Spencer, A., Bacchus, L., Hague, G. \& Warbuton, A. (2009). How far does screening women for domestic (partner) violence in different health-care settings meet criteria for a screening programme? Systematic reviews of nine UK National Screening Committee criteria. Health Technology Assessment, 13(16) 1-113.Ferris, J. A., \& Wynne, H. J. (2001). The Canadian problem gambling index: User manual. Canadian Centre on Substance Abuse.

Goodyear-Smith, F., Arroll, B., \& Coupe, N. (2009). Asking for help is helpful: validation of a brief lifestyle and mood assessment tool in primary health care. The Annals of Family Medicine, 7(3), 239-244.

Goodyear-Smith, F., Arroll, B., Kerse, N., Sullivan, S., Coupe, N., Tse, S., Shepherd, R., Rossen, F., \& Perese, L. (2006). Primary care patients reporting concerns about their gambling frequently have other co-occurring lifestyle and mental health issues. BMC family practice, 7(1), 25. 
Goodyear-Smith, F., Arroll, B., Sullivan, S., Elley, R., Docherty, B., \& Janes, R. (2004). Lifestyle screening: development of an acceptable multi-item general practice tool. New Zealand Medical Journal, 117(1205).

Goodyear-Smith, F., Coupe, N. M., Arroll, B., Elley, C. R., Sullivan, S., \& McGill, A. T. (2008). Case finding of lifestyle and mental health disorders in primary care: validation of the 'CHAT'tool. British Journal of General Practice, 58(546), 26-31.

Goodyear-Smith, F., Warren, J., Bojic, M., \& Chong, A. (2013). eCHAT for lifestyle and mental health screening in primary care. The Annals of Family Medicine, 11(5), 460-466.

Goodyear-Smith, F., Warren, J., \& Elley, C. R. (2013). The eCHAT program to facilitate healthy changes in New Zealand primary care. The Journal of the American Board of Family Medicine, 26(2), 177-182.

Grant, J. E., Schreiber, L., Odlaug, B. L., \& Kim, S. W. (2010). Pathologic gambling and bankruptcy. Comprehensive Psychiatry, 51(2), 115-120.

Greene, T., Neria, Y., \& Gross, R. (2016). Prevalence, detection and correlates of PTSD in the primary care setting: A systematic review. Journal of Clinical Psychology in Medical Settings, 23(2), $160-180$.

Griffiths, M. (2007). Gambling addiction and its treatment within the NHS [electronic resource]: a guide for healthcare professionals. British Medical Association. Board of Science.

Hartmann, M., \& Blaszczynski, A. (2018). The longitudinal relationships between psychiatric disorders and gambling disorders. International Journal of Mental Health and Addiction, 16(1), 16-44.

Health Survey for England (2018): https://digital.nhs.uk/data-andinformation/publications/statistical/health-survey-for-england/2018

Heirene, R. M. (2020). A call for replications of addiction research: which studies should we replicate and what constitutes a 'successful'replication?. Addiction Research \& Theory, 1-9. 
Higgins, J. P., Thompson, S. G., Deeks, J. J., \& Altman, D. G. (2003). Measuring inconsistency in metaanalyses. British Medical Journal, 327(7414), 557-560.

Hing, N., Holdsworth, L., Tiyce, M., \& Breen, H. (2014). Stigma and problem gambling: Current knowledge and future research directions. International Gambling Studies, 14(1), 64-81.

Hodgins, D. C., Stea, J. N., \& Grant, J. E. (2011). Gambling disorders. The Lancet, 378(9806), 18741884.

Jackson, C. (2007). The general health questionnaire. Occupational Medicine, 57(1), 79-79.

Jenkinson, C., Coulter, A., \& Wright, L. (1993). Short form 36 (SF36) health survey questionnaire: normative data for adults of working age. British Medical Journal, 306(6890), 1437-1440.

Johnson, E. E., Hamer, R., Nora, R. M., Tan, B., Eisenstein, N., \& Engelhart, C. (1997). The Lie/Bet Questionnaire for screening pathological gamblers. Psychological reports, 80(1), 83-88.

Kaner, E. F., Dickinson, H. O., Beyer, F., Pienaar, E., Schlesinger, C., Campbell, F., Saunders, J. B., Burnand, B., \& Heather, N. (2009). The effectiveness of brief alcohol interventions in primary care settings: a systematic review. Drug and Alcohol Review, 28(3), 301-323.

Krause, K., Bischof, A., Lewin, S., Guertler, D., Rumpf, H. J., John, U., \& Meyer, C. (2018). Explaining the relation between pathological gambling and depression: Rumination as an underlying common cause. Journal of Behavioral Addictions, 7(2), 384-391.

Kroenke, K., Spitzer, R. L., Williams, J. B., Monahan, P. O., \& Löwe, B. (2007). Anxiety disorders in primary care: prevalence, impairment, comorbidity, and detection. Annals of Internal Medicine, 146(5), 317-325.

Langham, E., Thorne, H., Browne, M., Donaldson, P., Rose, J., \& Rockloff, M. (2015). Understanding gambling related harm: A proposed definition, conceptual framework, and taxonomy of harms. BMC public health, 16(1), 80.

Lesieur, H. R., \& Blume, S. B. (1987). The South Oaks Gambling Screen (SOGS): a new instrument for the identification of pathological gamblers. American Journal of Psychiatry, 144(9), 11841188. 
Levens, S., Dyer, A. M., Zubritsky, C., Knott, K., \& Oslin, D. W. (2005). Gambling among older, primary-care patients: An important public health concern. The American Journal of Geriatric Psychiatry, 13(1), 69-76.

Liberati, A., Altman, D. G., Tetzlaff, J., Mulrow, C., Gøtzsche, P. C., loannidis, J. P., Clarke, M., Devereaux, P., Kleijnen, J., \& Moher, D. (2009). The PRISMA statement for reporting systematic reviews and meta-analyses of studies that evaluate health care interventions: explanation and elaboration. Journal of Clinical Epidemiology, 62(10), e1-e34.

Lorains, F. K., Cowlishaw, S., \& Thomas, S. A. (2011). Prevalence of comorbid disorders in problem and pathological gambling: Systematic review and meta-analysis of population surveys. Addiction, 106(3), 490-498.

Louderback, E. R., Wohl, M. J., \& LaPlante, D. A. (2020). Integrating open science practices into recommendations for accepting gambling industry research funding. Addiction Research \& Theory, 1-9.

Manthey, J., Gual, A., Jakubczyk, A., Pieper, L., Probst, C., Struzzo, P., Trapencieris, M., Wojnar, M., \& Rehm, J. (2016). Alcohol use disorders in Europe: A comparison of general population and primary health care prevalence rates. Journal of Substance Use, 21(5), 478-484.

Markham, F., Young, M., \& Doran, B. (2016). The relationship between player losses and gamblingrelated harm: evidence from nationally representative cross-sectional surveys in four countries. Addiction, 111(2), 320-330.

McHorney, C. A., Ware Jr, J. E., Lu, J. R., \& Sherbourne, C. D. (1994). The MOS 36-item Short-Form Health Survey (SF-36): III. Tests of data quality, scaling assumptions, and reliability across diverse patient groups. Medical Care, 40-66.

McNeely, J., Cleland, C. M., Strauss, S. M., Palamar, J. J., Rotrosen, J., \& Saitz, R. (2015). Validation of self-administered single-item screening questions (SISQs) for unhealthy alcohol and drug use in primary care patients. Journal of General Internal Medicine, 30(12), 1757-1764. 
Morasco, B. J., Vom Eigen, K. A., \& Petry, N. M. (2006). Severity of gambling is associated with physical and emotional health in urban primary care patients. General Hospital Psychiatry, 28(2), 94-100.

Morasco, B. J., Weinstock, J., Ledgerwood, D. M., \& Petry, N. M. (2007). Psychological factors that promote and inhibit pathological gambling. Cognitive and Behavioral Practice, 14(2), 208217.

Munn, Z., Moola, S., Lisy, K., Riitano, D., \& Tufanaru, C. (2015). Methodological guidance for systematic reviews of observational epidemiological studies reporting prevalence and cumulative incidence data. International Journal of Evidence-Based Healthcare, 13(3), 147153.

National Collaborating Centre for Mental Health. (2011). Alcohol use disorders: The NICE guideline on the diagnosis, assessment and management of harmful drinking and alcohol dependence (No. 115). RCPsych Publications.

Nehlin, C., Nyberg, F., \& Jess, K. (2016). Brief intervention within primary care for at-risk gambling: a pilot study. Journal of Gambling Studies, 32(4), 1327-1335.

Pasternak IV, A. V., \& Fleming, M. F. (1999). Prevalence of gambling disorders in a primary care setting. Archives of Family Medicine, 8(6), 515.

Petry, N. M. (2006). Internet gambling: an emerging concern in family practice medicine?. Family Practice, 23(4), 421-426.

Petry, N. M., \& Mallya, S. (2004). Gambling participation and problems among employees at a university health center. Journal of Gambling Studies, 20(2), 155-170.

Pilowsky, D. J., \& Wu, L. T. (2012). Screening for alcohol and drug use disorders among adults in primary care: a review. Substance Abuse and Rehabilitation, 3, 25.

Potenza, M. N. (2013). Neurobiology of gambling behaviors. Current Opinion in Neurobiology, 23(4), $660-667$.

Public Health England (2020). Gambling-related harms evidence review. 
https://www.gov.uk/government/publications/gambling-related-harms-evidencereview/gambling-related-harms-evidence-review-scope Accessed December 19, 2019.

Public Health England (2015). Criteria for appraising the viability, effectiveness and appropriateness of a screening programme. National Screening Committee. https://www.gov.uk/government/publications/evidence-review-criteria-national-screeningprogrammes/criteria-for-appraising-the-viability-effectiveness-and-appropriateness-of-ascreening-programme Accessed December 19, 2019.

Rehm, J. (2011). The risks associated with alcohol use and alcoholism. Alcohol Research \& Health, 34(2), 135.

Rigbye, J., \& Griffiths, M. D. (2011). Problem gambling treatment within the British national health service. International Journal of Mental Health and Addiction, 9(3), 276-281.

Roberts, A., Bowden-Jones, H., Roberts, D., \& Sharman, S. (2019). Should GPs routinely screen for gambling disorders? British Journal of General Practice, 69(682), 226-227.

Roberts, A., Landon, J., Sharman, S., Hakes, J., Suomi, A., \& Cowlishaw, S. (2018). Gambling and physical intimate partner violence: Results from the national epidemiologic survey on alcohol and related conditions (NESARC). The American Journal on Addictions, 27(1), 7-14.

Roberts, A., Sharman, S., King, M., Bayston, A., \& Bowden-Jones, H. (2019). Treatment-Seeking Problem Gamblers: Characteristics of Individuals Who Offend to Finance Gambling. International Journal of Mental Health and Addiction, 1-13.

Saitz, R. (2010). Alcohol screening and brief intervention in primary care: absence of evidence for efficacy in people with dependence or very heavy drinking. Drug and Alcohol Review, 29(6), 631-640.

Salonen, A. H., Hellman, M., Latvala, T., \& Castrén, S. (2018). Gambling participation, gambling habits, gambling-related harm, and opinions on gambling advertising in Finland in 2016. Nordic Studies on Alcohol and Drugs, 35(3), 215-234. 
Sanju, G., \& Gerada, C. (2011). Problem gamblers in primary care: can GPs do more? British Journal of General Practice, 61(585), 248-249.

Sharman, S., Butler, K., \& Roberts, A. (2019). Psychosocial risk factors in disordered gambling: A descriptive systematic overview of vulnerable populations. Addictive Behaviors, 99, 106071.

Spitzer, R. L., Williams, J. B., Kroenke, K., Linzer, M., deGruy, F. V., Hahn, S. R., Brody, D., \& Johnson, J. G. (1994). Utility of a new procedure for diagnosing mental disorders in primary care: the PRIME-MD 1000 study. Jama, 272(22), 1749-1756.

Spoont, M. R., Williams, J. W., Kehle-Forbes, S., Nieuwsma, J. A., Mann-Wrobel, M. C., \& Gross, R. (2015). Does this patient have posttraumatic stress disorder?: Rational clinical examination systematic review. Jama, 314(5), 501-510.

Sullivan, S. (2007). Don't let an opportunity go by: Validation of the EIGHT gambling screen. International Journal of Mental Health and Addiction, 5(4), 381-389.

Sullivan, S., McCormick, R., Lamont, M., \& Penfold, A. (2007). Problem gambling: patients affected by their own or another's gambling may approve of help from general practitioners. The New Zealand Medical Journal, 120(1257), U2605.

Sundqvist, K., \& Rosendahl, I. (2019). Problem Gambling and Psychiatric Comorbidity-Risk and Temporal Sequencing Among Women and Men: Results from the Swelogs Case-Control Study. Journal of Gambling Studies, 35(3), 757-771

The, Lancet. (2017). Problem gambling is a public health concern. Lancet, 390(10098), 913.

Toce-Gerstein, M., Gerstein, D. R., \& Volberg, R. A. (2009). The NODS-CLiP: A rapid screen for adult pathological and problem gambling. Journal of Gambling Studies, 25(4), 541.

Tolchard, B., Thomas, L., \& Battersby, M. (2007). GPs and problem gambling: can they help with identification and early intervention? Journal of Gambling Studies, 23(4), 499-506.

Tracy, J. K., Maranda, L., \& Scheele, C. (2018). Statewide Gambling Prevalence in Maryland: 2017. Maryland Center of Excellence on Problem Gambling. 
Volberg, R. A., Munck, I. M., \& Petry, N. M. (2011). A quick and simple screening method for pathological and problem gamblers in addiction programs and practices. The American Journal on Addictions, 20(3), 220-227.

Ware, J. E., Kosinski, M., \& Keller, S. D. (1996). A 12-Item Short-Form Health Survey: Construction of Scales and Preliminary Tests of Reliability and Validity. Medical Care, 34(3), 220-233.

Whooley, M. A., Avins, A. L., Miranda, J., \& Browner, W. S. (1997). Case-finding instruments for depression: Two questions are as good as many. Journal of General Internal Medicine, 12(7), 439-445.

Young, M. (2013). Statistics, scapegoats and social control: A critique of pathological gambling prevalence research. Addiction Research \& Theory, 21(1), 1-11. 


\section{Appendices:}

Search String:

\begin{tabular}{|l|l|}
\hline \multicolumn{1}{|c|}{$\#$} & \multicolumn{1}{|c|}{ Query } \\
\hline S1 & (MH "Gambling") \\
\hline S2 & TI problem* N2 gambl* OR AB problem* N2 gambl* \\
\hline S3 & TI addict* N2 gambl* OR AB addict* N2 gambl* \\
\hline S4 & TI disorder* N2 gambI* OR AB disorder* N2 gambl* \\
\hline S5 & S1 OR S2 OR S3 OR S4 \\
\hline S6 & (MH "General Practice+") \\
\hline S7 & (MH "Primary Health Care") \\
\hline S8 & (MH "Community Health Services") \\
\hline S9 & (MH "Physicians, Primary Care") \\
\hline S10 & (MH "Physicians, Family") \\
\hline S11 & (MH "General Practitioners") \\
\hline S12 & $\begin{array}{l}\text { TX (general pract* OR family pract* OR GP OR physician* OR community) OR ((family } \\
\text { nurs*)) OR (primary N2 care) }\end{array}$ \\
\hline S13 & S6 OR S7 OR S8 OR S9 OR S10 OR S11 OR S12 \\
\hline S14 & S5 AND S13 \\
\hline
\end{tabular}

\section{Biographical notes:}

Dr Amanda Roberts: Amanda is an Associate Professor in Psychology at the University of Lincoln, with a PhD in Behavioural Neuroscience from Cardiff University and previous research and lectureship positions at UK academic institutions. She has numerous multidisciplinary collaborations including an honorary research contract at the National Problem Gambling Clinic and a Research Fellowship at the Gambling Addictions Research Centre, AUT, NZ. Amanda's research interests include the evaluation of gambling addiction treatment programmes both in the community and in UK prisons and additional interests extend across topics that relate to gambling comorbidity, gambling in vulnerable populations, and gambling and interpersonal violence.

Dr Jim Rogers: Jim had a career in mental health nursing for eleven years before moving into the voluntary sector for several years. He taught adults in further and adult education for a number of years before moving into higher education. Jim has taught at the university since 2000 , on a variety of health and social care programmes, largely those relating to social work. He has been co -ordinator for the first year of the social work degree and is currently programme leader for professional post graduate courses relating to mental health and mental capacity. In terms of research activity, Jim has 
undertaken systematic reviews in relation to gambling, complementary therapies, research in care homes, reviews of the role of social work in responding to gambling problems, and research with students in relation to digital literacies.

Dr Stephen Sharman: Steve is an academic researcher who specialises in gambling behaviour. He has a PhD in Experimental Psychology from the University of Cambridge, where his thesis explored cognitive distortions and decision-making in gambling behaviour. He is a current Society for the Study of Addiction (SSA) Griffith Edwards Academic Fellow at the University of East London, where he uses Virtual Reality to research gambling behaviour. Steve is also a Research Fellow (Gambling Studies) at the National Addiction Centre, Kings College London where he works closely with the National Problem Gambling Clinics.

Professor G.J. Melendez-Torres: G.J. arrived at the University of Exeter in March 2019 to take up a personal chair in clinical and social epidemiology. As part of this, he leads the Peninsula Technology Assessment Group (PenTAG), one of nine research units in the UK providing expert advice on the clinical and cost effectiveness of new drugs to the National Institute for Health and Care Excellence. He is also Deputy Director of the Exeter NIHR Policy Research Programme Evidence Reviews Facility. His interest in health technology assessment stems from an enjoyment of the kinds of knotty methodological problems, both statistical and conceptual, that this area can present, as well as an appreciation for the impact that timely and rigorous scientific advice can have on the policy process. Indeed, the development of methods to support HTA and systematic reviews of complex interventions is his major research focus.

Dr Sean Cowlishaw: Sean is a Senior Research Fellow in the Department of Psychiatry at the University of Melbourne, and the Phoenix Australia Centre for Posttraumatic Mental Health. He is also an Honorary Senior Research Fellow with the Bristol Medical School at the University of Bristol. Sean completed his PhD in psychology at La Trobe University in 2009, which addressed the impacts of occupational and traumatic stressors on families of volunteer emergency service workers. He has since held positions at Monash University (Australia) and Lancaster University (UK), and most recently within the Centre for Academic Primary Care at the University of Bristol (UK). Sean has primary expertise in gambling problems and addictive behaviours, including treatments and comorbidities, early identification and interventions, as well as industry influences on research. He also has significant research interests and expertise in post-traumatic mental health and Intimate Partner Violence (IPV), as well as health services research and high-risk organisations (e.g., military and emergency services). 
Table 1: Characteristics of included studies

\begin{tabular}{|c|c|c|c|c|c|c|c|c|c|c|}
\hline Author(s), year & $\begin{array}{l}\text { Sample } \\
\text { size } \\
\text { (n) } \\
\text { Country }\end{array}$ & $\begin{array}{c}\text { Primary care } \\
\text { setting }\end{array}$ & Age & $\begin{array}{c}\text { Gender } \\
\% \\
\text { female }\end{array}$ & $\begin{array}{l}\text { Measure of } \\
\text { PG }\end{array}$ & Recruitment & $\begin{array}{c}\text { Respons } \\
\text { e rate } \\
\quad \%\end{array}$ & $\begin{array}{l}\text { Prevalence of } \\
\text { gambling } \\
\text { problems } \\
(95 \% \mathrm{CI})\end{array}$ & $\begin{array}{l}\text { Additional analyses } \\
\text { (Clinical) }\end{array}$ & $\begin{array}{l}\text { Clinical covariates with } \\
\text { problem gambling }\end{array}$ \\
\hline $\begin{array}{l}\text { Cowlishaw, } \\
\text { Gale, Gregory, } \\
\text { McCambridge \& } \\
\text { Kessler (2017) }\end{array}$ & $\begin{array}{l}1058 \\
\text { UK }\end{array}$ & $\begin{array}{l}\text { Eleven general } \\
\text { practices in areas } \\
\text { of varied } \\
\text { deprivation levels } \\
\text { Including four } \\
\text { practices from } \\
\text { the top } 30 \% \\
\text { deprived } \\
\text { areasone student } \\
\text { health care } \\
\text { service and one } \\
\text { practice for the } \\
\text { homeless }\end{array}$ & $\begin{array}{l}20.7 \%(18- \\
24) ; 15.1 \% \\
(25-34) ; \\
13.4 \%(35- \\
44) ; 27.8 \% \\
(45-64) ; \\
23.0 \% \text { (>65 } \\
\text { yrs) }\end{array}$ & 64.7 & $\begin{array}{l}\text { PGSI } \\
\text { NODS CLIP }\end{array}$ & $\begin{array}{l}\text { Patients were } \\
\text { approached by } \\
\text { the researcher in } \\
\text { waiting rooms } \\
\text { before } \\
\text { appointments } \\
\text { and provided with } \\
\text { information } \\
\text { about the study }\end{array}$ & $\begin{array}{l}\text { Not } \\
\text { reported }\end{array}$ & $\begin{array}{l}\text { PGSI: } 1-4: 4.3 \% \\
\text { (95\% CI 3.2\% to } \\
5.7 \%) \\
\text { PGSI: } \geq 5: 0.9 \% \\
(95 \% \text { Cl } 0.5 \% \text { to } \\
1.8 \%) \\
\text { NODS CLIP: } \\
3.3 \% \text { (95\% } \\
\text { CI } 2.3 \%-4.6 \%) \\
\text { Overall (any } \\
\text { gambling } \\
\text { problems): } 5.2 \% \\
\text { (95\% Cl } 4.0 \% \text { to } \\
6.8 \%)\end{array}$ & $\begin{array}{l}\text { Depression (Two- } \\
\text { item Whooley Scale), } \\
\text { anxiety (GAD-2), risky } \\
\text { alcohol use (AUDIT- } \\
\text { C), non-prescription } \\
\text { and recreational drug } \\
\text { use (SISQ) } \\
\text { Gambling problems } \\
\text { among family } \\
\text { members }\end{array}$ & $\begin{array}{l}\text { Patients screening positive } \\
\text { for depression } \\
\text { demonstrated a twofold } \\
\text { increase in rates of } \\
\text { gambling problems (OR } \\
2.08,95 \% \mathrm{Cl}=1.15 \text { to } \\
3.94 \text { ), while risky alcohol } \\
\text { use was associated with a } \\
\text { near threefold increase } \\
\text { (OR } 2.78,95 \% \mathrm{Cl}=1.60 \text { to } \\
4.89 \text { ) } \\
\text { Drug use was associated } \\
\text { with a fivefold increase in } \\
\text { gambling problems (OR } \\
5.03,95 \% \mathrm{Cl}=2.78 \text { to } \\
8.99 \text { ) } \\
\text { No significant association } \\
\text { between individuals who } \\
\text { screened positive for } \\
\text { anxiety and gambling } \\
\text { problems }\end{array}$ \\
\hline
\end{tabular}




\begin{tabular}{|c|c|c|c|c|c|c|c|c|c|c|}
\hline $\begin{array}{l}\text { Elley et al., } \\
\text { (2014) }\end{array}$ & 265 & $\begin{array}{l}\text { Two family } \\
\text { practices } \\
\text { (one university } \\
\text { affiliated and one } \\
\text { inner city health } \\
\text { centre providing } \\
\text { primary care for } \\
\text { adults without } \\
\text { medical coverage) }\end{array}$ & $19+$ & $\begin{array}{l}\text { Not } \\
\text { reported }\end{array}$ & $\begin{array}{l}\text { Two } \\
\text { gambling } \\
\text { questions } \\
\text { within CHAT } \\
\text { (Health } \\
\text { Assessment } \\
\text { tool) "Does } \\
\text { gambling } \\
\text { sometimes } \\
\text { cause you } \\
\text { problems" } \\
\text { and "Do you } \\
\text { sometimes } \\
\text { feel } \\
\text { unhappy or } \\
\text { worried } \\
\text { after a } \\
\text { session of } \\
\text { gambling" }\end{array}$ & $\begin{array}{l}\text { Consecutive } \\
\text { patients } \\
\text { attending two } \\
\text { practices during } \\
\text { practice hours } \\
\text { over six separate } \\
\text { days invited to } \\
\text { participate by a } \\
\text { research assistant } \\
\text { in the waiting } \\
\text { room }\end{array}$ & 91.00 & $\begin{array}{l}\text { Unhappy or } \\
\text { worried: } 2 \% \\
\text { Gambling } \\
\text { causes } \\
\text { problems: } 2 \%\end{array}$ & $\begin{array}{l}\text { Smoking, alcohol use, } \\
\text { drug use, depression, } \\
\text { anxiety, } \\
\text { Interpersonal } \\
\text { Violence (IPV), anger } \\
\text { control, exercise } \\
\text { Assistance with } \\
\text { gambling }\end{array}$ & $\begin{array}{l}\text { Not used in relation to } \\
\text { problem gambling in the } \\
\text { analysis }\end{array}$ \\
\hline $\begin{array}{l}\text { Goodyear-Smith } \\
\text { et al. (2006) }\end{array}$ & $\begin{array}{l}2536 \\
N Z\end{array}$ & $\begin{array}{l}\text { Primary care } \\
\text { providers in three } \\
\text { locations in } \\
\text { Auckland (urban), } \\
\text { Otago (mixed } \\
\text { urban/rural), and } \\
\text { Hawke's Bay } \\
\text { (rural). } 20 \\
\text { randomly- } \\
\text { selected urban } \\
\text { general } \\
\text { practitioners, } 20 \\
\text { general practice } \\
\text { nurses, } 11 \text { rural } \\
\text { general } \\
\text { practitioners }\end{array}$ & $\begin{array}{l}\text { Range: } 16- \\
91 \\
\text { Mean age } \\
\text { ranged } \\
\text { from } 46 \text { - } \\
49 \text { across } \\
\text { sites }\end{array}$ & 67 & $\begin{array}{l}\text { MIST: Single } \\
\text { item: Have } \\
\text { you } \\
\text { sometimes } \\
\text { felt unhappy } \\
\text { or worried } \\
\text { after a } \\
\text { session of } \\
\text { gambling? }\end{array}$ & $\begin{array}{l}51 \text { care providers } \\
\text { (physicians and } \\
\text { practice nurses) } \\
\text { selected } \\
\text { (randomly or all } \\
\text { providers in one } \\
\text { setting). Fifty } \\
\text { consecutive adult } \\
\text { patients (over } 16 \\
\text { years) per } \\
\text { provider were } \\
\text { invited to } \\
\text { participate. } \\
\text { Lifestyle } \\
\text { screening forms } \\
\text { self-administered } \\
\text { by patients on the }\end{array}$ & $\begin{array}{l}97.80 \text { in } \\
\text { one } \\
\text { setting } \\
\text { Not } \\
\text { recorded } \\
\text { in others } \\
\text { but } \\
\text { stated } \\
\text { that it is } \\
\text { unlikely } \\
\text { to differ } \\
\text { across } \\
\text { the } \\
\text { settings }\end{array}$ & $\begin{array}{l}\text { Unhappy or } \\
\text { worried: } 3.2 \% \\
\text { (Cl } 2.6 \text { to } 4.0 \text { ) }\end{array}$ & $\begin{array}{l}\text { Smoking, alcohol use, } \\
\text { drug use, depression, } \\
\text { anxiety, IPV, anger } \\
\text { control, exercise, } \\
\text { weight } \\
\text { Assistance with } \\
\text { gambling }\end{array}$ & $\begin{array}{l}\text { Odds or worry about } \\
\text { gambling and other factor } \\
\text { compared to worry about } \\
\text { other factor alone. } \\
\text { Smoking (OR: } 3.9 \mathrm{Cl} \text { : } \\
2.12-5.44 \text { ), drinking (OR: } \\
2.74 \mathrm{Cl} \text { : } 1.64-4.55 \text { ), drug } \\
\text { use (OR: } 5.23 \mathrm{Cl}: 2.51- \\
\text { 10.9), depression (OR: } \\
2.84 \mathrm{Cl}: 1.7-4.75 \text { and OR: } \\
2.5 \mathrm{Cl}: 1.67-3.81 \text { ), worry } \\
\text { (OR: } 2.21 \mathrm{Cl}: 1.38-3.55) \text {, } \\
\text { anger control (OR: } 2.52 \\
\mathrm{Cl}: 1.44-4.43)\end{array}$ \\
\hline
\end{tabular}




\begin{tabular}{|c|c|c|c|c|c|c|c|c|c|c|}
\hline & & & & & & $\begin{array}{l}\text { waiting room, or } \\
\text { administered by a } \\
\text { practice nurse in } \\
\text { the consulting } \\
\text { room }\end{array}$ & & & & $\begin{array}{l}\text { No significant associations } \\
\text { with concerns about IPV, } \\
\text { weight or physical activity }\end{array}$ \\
\hline $\begin{array}{l}\text { Goodyear-Smith } \\
\text { et al. (2008) }\end{array}$ & $\begin{array}{l}995 \\
\mathrm{NZ}\end{array}$ & $\begin{array}{l}\text { Two primary care } \\
\text { practices in } \\
\text { Auckland } \\
\text { including } \\
\text { practices in a } \\
\text { socio- } \\
\text { economically } \\
\text { deprived area in } \\
\text { South Auckland }\end{array}$ & $\begin{array}{l}21 \%(16- \\
29) ; 37 \% \\
(30-49) ; \\
42 \%(>50 \\
\text { years })\end{array}$ & 71 & $\begin{array}{l}\text { CHAT "Do } \\
\text { you } \\
\text { sometimes } \\
\text { feel } \\
\text { unhappy or } \\
\text { worried } \\
\text { after a } \\
\text { session of } \\
\text { gambling" } \\
\text { and "Does } \\
\text { gambling } \\
\text { sometimes } \\
\text { cause you } \\
\text { problems" } \\
\text { soGS }\end{array}$ & $\begin{array}{l}\text { All consecutive } \\
\text { adult patients } \\
\text { (over 16) } \\
\text { attending GP } \\
\text { practices until } \\
\text { target sample of } \\
1000 \text { reached. } \\
\text { Forms self- } \\
\text { administered by } \\
\text { patients in the } \\
\text { waiting room. }\end{array}$ & 91.40 & $\begin{array}{l}\text { SOGS: } \\
\text { Problematic } \\
\text { Gambling: 1.8\% } \\
\text { Assessed } \\
\text { criterion-based } \\
\text { validity of CHAT } \\
\text { against the 'gold } \\
\text { standard' } \\
\text { measure of } \\
\text { SOGS. } \\
\text { Likelihood ratio } \\
\text { (odds of having } \\
\text { the condition) } \\
30.05 \text { (17.71 to } \\
45.81 \text { ) }\end{array}$ & $\begin{array}{l}\text { Smoking, alcohol use, } \\
\text { drug use, depression, } \\
\text { anxiety, IPV, anger } \\
\text { control, exercise, } \\
\text { eating disorder }\end{array}$ & $\begin{array}{l}\text { Not used in relation to } \\
\text { problem gambling in the } \\
\text { analysis }\end{array}$ \\
\hline $\begin{array}{l}\text { Goodyear- } \\
\text { Smith, Arroll \& } \\
\text { Coupe (2009) }\end{array}$ & $\begin{array}{l}755 \\
N Z\end{array}$ & $\begin{array}{l}\text { Primary care } \\
\text { practices in South } \\
\text { Auckland } \\
\text { including socio- } \\
\text { economically } \\
\text { deprived } \\
\text { populations in } \\
\text { Auckland's North } \\
\text { Shore }\end{array}$ & $\begin{array}{l}\text { Not } \\
\text { reported }\end{array}$ & $\begin{array}{l}\text { Not } \\
\text { reported }\end{array}$ & $\begin{array}{l}\text { CHAT and } \\
\text { SOGS }\end{array}$ & $\begin{array}{l}\text { Consecutive } \\
\text { primary health } \\
\text { care patients } \\
\text { aged } 16 \text { years and } \\
\text { older recruited } \\
\text { from waiting } \\
\text { room by RA to } \\
\text { complete CHAT } \\
\text { with help Qs and }\end{array}$ & 98.00 & $\begin{array}{l}\text { CHAT positive } \\
\text { for gambling: } \\
0.6 \% \text {. } \\
\text { SOGS (4+): } 0.7 \%\end{array}$ & $\begin{array}{l}\text { Smoking, alcohol use, } \\
\text { drug use, depression, } \\
\text { anxiety, IPV, anger } \\
\text { control } \\
\text { Assistance with } \\
\text { gambling }\end{array}$ & $\begin{array}{l}\text { Not used in relation to } \\
\text { problem gambling in the } \\
\text { analysis }\end{array}$ \\
\hline
\end{tabular}




\begin{tabular}{|c|c|c|c|c|c|c|c|c|c|c|}
\hline & & & & & & $\begin{array}{l}\text { reference } \\
\text { standard (SOGS). } \\
\text { Forms self- } \\
\text { administered by } \\
\text { patients in the } \\
\text { waiting room }\end{array}$ & & & & \\
\hline $\begin{array}{l}\text { Goodyear- } \\
\text { Smith, Warren, } \\
\text { Bojic \& Chong } \\
\text { (2013) }\end{array}$ & $\begin{array}{l}233 \\
N Z\end{array}$ & $\begin{array}{l}\text { Two family } \\
\text { practices in } \\
\text { Auckland } \\
\text { including one in a } \\
\text { relatively } \\
\text { deprived } \\
\text { neighbourhood }\end{array}$ & $\begin{array}{l}\text { Not } \\
\text { obtained }\end{array}$ & $\begin{array}{l}\text { Not } \\
\text { obtained }\end{array}$ & $\begin{array}{l}\text { Web based } \\
\text { eCHAT }\end{array}$ & $\begin{array}{l}\text { Consecutive adult } \\
\text { patients (over } 16 \\
\text { years) } \\
\text { approached in the } \\
\text { waiting room and } \\
\text { invited to } \\
\text { participate. } \\
\text { Questionnaire } \\
\text { self-administered } \\
\text { by patients on a } \\
\text { tablet computer }\end{array}$ & 91.00 & $1.1 \%$ (eCHAT) & $\begin{array}{l}\text { Smoking, alcohol use, } \\
\text { drug use, depression, } \\
\text { anxiety, IPV, anger } \\
\text { control, exercise } \\
\text { Assistance with } \\
\text { gambling }\end{array}$ & $\begin{array}{l}\text { Not used in relation to } \\
\text { problem gambling in the } \\
\text { analysis }\end{array}$ \\
\hline $\begin{array}{l}\text { Levens, Dyer, } \\
\text { Zubritsky, Knott } \\
\text { \& Oslin (2005) }\end{array}$ & $\begin{array}{l}843 \\
\text { U.S. }\end{array}$ & $\begin{array}{l}\text { Primary care } \\
\text { practices from } \\
\text { two sites } \\
\text { (Philadelphia VA } \\
\text { Medical Centre, } \\
\text { University of } \\
\text { Pennsylvania) of a } \\
\text { multisite trial of } \\
\text { mental health } \\
\text { care models in } \\
\text { primary care } \\
\text { (PRISM-E) }\end{array}$ & $\begin{array}{l}\text { Mean (SD) } \\
=74.1 \\
(6.0) ; \\
\text { Range: } 65+ \\
\text { years }\end{array}$ & 29.8 & $\begin{array}{l}\text { Two items } \\
\text { indicating } \\
\text { 'at-risk' } \\
\text { gambling: } \\
\text { Gambled } \\
\text { more than } \\
\$ 100 \text { on a } \\
\text { single bet } \\
\text { Bet more } \\
\text { than they } \\
\text { could afford } \\
\text { to lose (past } \\
\text { year) }\end{array}$ & $\begin{array}{l}\text { Each week during } \\
\text { the trial a random } \\
\text { subset of patients } \\
\text { were selected } \\
\text { from the practice } \\
\text { appointment list } \\
\text { and sent a letter } \\
\text { about screening. } \\
\text { Participants who } \\
\text { had not declined } \\
\text { participation } \\
\text { were contacted } \\
\text { via telephone }\end{array}$ & 58.90 & $\begin{array}{l}10.9 \% \text { (scores } \\
\text { on either item)- } \\
\text { At-risk gamblers } \\
\text { (1) Gambled } \\
\text { more than } \$ 100 \\
\text { on a single bet: } \\
7.7 \% \\
\text { (2) Bet more } \\
\text { than they could } \\
\text { afford to lose } \\
\text { (past year): } \\
4.2 \%\end{array}$ & $\begin{array}{l}\text { Smoking, self-rated } \\
\text { health (MOS SF-36), } \\
\text { cognitive status } \\
\text { (BOMC), depression } \\
\text { (GHQ), at-risk alcohol } \\
\text { use, binge drinking, } \\
\text { suicidal ideation } \\
\text { (PRIME-MD) post- } \\
\text { traumatic stress } \\
\text { disorder, across } \\
\text { problem gambling } \\
\text { categories }\end{array}$ & $\begin{array}{l}\text { Compared to non- } \\
\text { gamblers, the strongest } \\
\text { predictors of at-risk } \\
\text { gambling were being a } \\
\text { binge drinker (OR: } 6.27 \\
\text { 95\% Cl: } 1.58-24.86) \text {, and } \\
\text { PTSD (OR: } 2.7995 \% \mathrm{Cl} \text { : } \\
\text { 1.43-5.44) } \\
\text { Compared to recreational } \\
\text { gamblers, the strongest } \\
\text { predictors of at-risk } \\
\text { gambling was the risk of } \\
\text { PTSD (OR: } 2.6895 \% \mathrm{Cl} \text { : } \\
\text { 1.45-4.48) }\end{array}$ \\
\hline
\end{tabular}




\begin{tabular}{|c|c|c|c|c|c|c|c|c|c|c|}
\hline & & & & & $\begin{array}{l}\text { Gambling } \\
\text { activities } \\
\text { (past year) } \\
\text { derived from } \\
\text { the SOGS } \\
\text { Amount } \\
\text { spent on a } \\
\text { single bet in } \\
\text { the past } \\
\text { year } \\
\text { (Recreationa } \\
\text { I) }\end{array}$ & & & $\begin{array}{l}\text { Both gambling } \\
\text { problems } \\
(0.95 \%)\end{array}$ & & $\begin{array}{l}\text { Compared to non- } \\
\text { gamblers, the strongest } \\
\text { predictor of recreational } \\
\text { gambling was the risk of } \\
\text { being a binge drinker (OR: } \\
4.38 \text { 95\% Cl: 1.31-14.69) } \\
\text { At-risk gambling behavior } \\
\text { was not significantly } \\
\text { associated with current or } \\
\text { past depressive } \\
\text { symptoms, suicidal } \\
\text { ideation, cognitive } \\
\text { impairment, self-rated } \\
\text { health, at-risk alcohol use, } \\
\text { or cigarette smoking. }\end{array}$ \\
\hline $\begin{array}{l}\text { Morasco, vom } \\
\text { Eigen, \& Petry } \\
\text { (2006) }\end{array}$ & $\begin{array}{l}574 \\
\text { U.S. }\end{array}$ & $\begin{array}{l}\text { Urban primary } \\
\text { care practice in } \\
\text { Hartford, CT } \\
\text { which served a } \\
\text { low-income } \\
\text { population }\end{array}$ & $\begin{array}{l}\text { Mean (SD) } \\
=37.2 \\
(13.7)\end{array}$ & 75.0 & $\begin{array}{l}\begin{array}{l}\text { SOGS } \\
\text { (lifetime) }\end{array} \\
\text { Frequency } \\
\text { and amount } \\
\text { spent } \\
\text { gambling } \\
\text { (last 2 } \\
\text { months) } \\
\text { Types of } \\
\text { gambling } \\
\text { activities } \\
\text { (lifetime) }\end{array}$ & $\begin{array}{l}\text { Patients } \\
\text { approached in the } \\
\text { practice and } \\
\text { invited to } \\
\text { participate by a } \\
\text { research assistant }\end{array}$ & $\approx 80$ & $\begin{array}{l}\text { SOGS 3-4: } 5.1 \% \\
(95 \% \mathrm{Cl}=3.5 \text { to } \\
7.2) \\
\text { SOGS } 5+: 10.6 \% \\
(95 \% \mathrm{Cl}=8.2 \text { to } \\
13.4)\end{array}$ & $\begin{array}{l}\text { Measured physical } \\
\text { and emotional } \\
\text { functioning. } \\
\text { Compared Short } \\
\text { Form Health Survey } \\
\text { Version } 2 \text { (SF-12v2) } \\
\text { scores across } \\
\text { problem gambling } \\
\text { categories }\end{array}$ & $\begin{array}{l}\text { Pathological gamblers } \\
\text { reported significantly } \\
\text { worse functioning on all } \\
\text { eight index scores- } \\
\text { physical functioning, role } \\
\text { physical, bodily pain, } \\
\text { general health, vitality, } \\
\text { social functioning, role- } \\
\text { emotional and mental } \\
\text { health compared to non- } \\
\text { gamblers and recreational } \\
\text { gamblers } \\
\text { Problem gamblers } \\
\text { reported worse } \\
\text { functioning on six scores- } \\
\text { physical functioning, role } \\
\text { physical, bodily pain, } \\
\text { general health, vitality and }\end{array}$ \\
\hline
\end{tabular}




\begin{tabular}{|c|c|c|c|c|c|c|c|c|c|c|}
\hline & & & & & & & & & & $\begin{array}{l}\text { mental health than non- } \\
\text { gamblers }\end{array}$ \\
\hline $\begin{array}{l}\text { Nehlin, Nyberg } \\
\text { \& Jess (2016) }\end{array}$ & $\begin{array}{l}537 \\
\text { Swede } \\
\mathrm{n}\end{array}$ & $\begin{array}{l}\text { Three primary } \\
\text { health care } \\
\text { centres in } \\
\text { Swedish cities } \\
\text { (two of the } \\
\text { centres received } \\
\text { patients from } \\
\text { local } \\
\text { neighbourhoods) }\end{array}$ & $\begin{array}{l}43.7 \\
(16.2)\end{array}$ & $\begin{array}{l}\text { Not } \\
\text { reported }\end{array}$ & $\begin{array}{l}4 \text { items on } \\
\text { the NODS- } \\
\text { PERC }\end{array}$ & $\begin{array}{l}\text { Contact person } \\
\text { (nurses and social } \\
\text { worker) invited all } \\
\text { new and ongoing } \\
\text { patients to } \\
\text { participate. A } \\
\text { consultant } \\
\text { approached } \\
\text { patients in } \\
\text { waiting room }\end{array}$ & $\begin{array}{l}\text { Not } \\
\text { reported }\end{array}$ & $\begin{array}{l}\text { Screen positive } \\
\text { for problem } \\
\text { gambling: } 6.3 \%\end{array}$ & Not reported & Not reported \\
\hline $\begin{array}{l}\text { Pasternak \& } \\
\text { Fleming (1999) }\end{array}$ & $\begin{array}{l}1051 \\
\text { U.S }\end{array}$ & $\begin{array}{l}\text { Three primary } \\
\text { care clinics in } \\
\text { Wisconsin } \\
\text { including one in a } \\
\text { low-income area } \\
\text { of Madison }\end{array}$ & $\begin{array}{l}\text { Mean (SD) } \\
=43.1 \\
(16.1)\end{array}$ & 63.8 & $\begin{array}{l}\text { SOGS } \\
\text { (lifetime } \\
\text { gambling) }\end{array}$ & $\begin{array}{l}\text { Invitations to } \\
\text { participate made } \\
\text { prior to meeting } \\
\text { with physician }\end{array}$ & 75.40 & $\begin{array}{l}\text { SOGS 3-4: } 3.4 \% \\
\text { (2.4 to } 4.7) \\
\text { SOGS 5+: } 2.8 \% \\
\text { (1.9 to } 3.9 \text { ) } \\
\text { Overall } \\
\text { gambling } \\
\text { disorder: } 6.2 \%\end{array}$ & $\begin{array}{l}\text { Compared smoking, } \\
\text { alcohol use, alcohol } \\
\text { abuse (CAGE), } \\
\text { marijuana use, } \\
\text { depression, anxiety } \\
\text { and physical health } \\
\text { (items from SF-36), } \\
\text { across problem } \\
\text { gambling categories }\end{array}$ & $\begin{array}{l}\text { Patients with gambling } \\
\text { disorders (SOGS } 3+\text { ) were } \\
\text { more likely to use tobacco } \\
\text { (OR: } 3.17 \mathrm{Cl}: 1.69-5.95) \\
\text { and abuse alcohol (OR: } \\
2.43 \mathrm{Cl} \text { : } 1.19-12.07) \\
\text { compared with non- } \\
\text { gamblers and non- } \\
\text { problem gamblers } \\
\text { Patients with gambling } \\
\text { disorders rated their } \\
\text { health as being worse } \\
\text { compared to patients } \\
\text { without gambling } \\
\text { disorders. Pathological } \\
\text { gamblers had more severe }\end{array}$ \\
\hline
\end{tabular}




\begin{tabular}{|c|c|c|c|c|c|c|c|c|c|c|}
\hline & & & & & & & & & & $\begin{array}{l}\text { symptoms of heartburn or } \\
\text { abdominal pains and } \\
\text { backache } \\
\text { A positive relationship } \\
\text { between patients with } \\
\text { gambling disorders and } \\
\text { those answering } \\
\text { affirmatively to the } \\
\text { depression and anxiety } \\
\text { symptoms } \\
\text { No relationship between } \\
\text { marijuana use and } \\
\text { gambling disorders } \\
\text { although weak trend with } \\
\text { patients who used more } \\
\text { marijuana in a lifetime }\end{array}$ \\
\hline $\begin{array}{l}\text { Sullivan, } \\
\text { McCormick, } \\
\text { Lamont and } \\
\text { Penfold (2007) }\end{array}$ & $\begin{array}{l}1580 \\
N Z\end{array}$ & $\begin{array}{l}\text { Sixteen primary } \\
\text { care practices in } \\
\text { Auckland, } \\
\text { Taranaki and } \\
\text { Rotorua }\end{array}$ & $\begin{array}{l}\text { Not } \\
\text { reported. }\end{array}$ & 58 & EIGHT & $\begin{array}{l}\text { All patients } \\
\text { presenting to the } \\
\text { practices were } \\
\text { invited to } \\
\text { participate by the } \\
\text { receptionist }\end{array}$ & $\begin{array}{l}\text { Very few } \\
\text { in any } \\
\text { refused } \\
\text { to take } \\
\text { part }\end{array}$ & $\begin{array}{l}\text { EIGHT: } 7.5 \% \\
\text { (range 3\% to } \\
24 \% \text { ) } \\
\text { COGS: } 15 \%\end{array}$ & $\begin{array}{l}\text { Compared socio- } \\
\text { demographics and } \\
\text { depression (two } \\
\text { question depression } \\
\text { screen- Whooley) } \\
\text { across problem } \\
\text { gambling categories } \\
\text { Reported frequency } \\
\text { of perceptions that } \\
\text { GPs could help with } \\
\text { gambling problems } \\
\text { COGS screen: } 11 \% \\
\text { affected by another's } \\
\text { gambling }\end{array}$ & $\begin{array}{l}63.4 \% \text { of problem } \\
\text { gamblers positive on } \\
\text { depression screen. } \\
\text { Problem gambling found } \\
\text { to affect the presence of } \\
\text { depression (OR 2.4) }\end{array}$ \\
\hline
\end{tabular}


AUDIT-C (Alcohol Use Disorders Identification Test), BOMC (Brief Orientation Memory Concentration Test), CAGE (acronym of its four questions; Cut Down, Annoyed, Guilty, Eye-opener), CHAT (Case-finding and Help Assessment Tool), COGS (Concerned Others Gambling Screen), eCHAT (Electronic version of the Casefinding and Help Assessment Tool), EIGHT (Early Intervention Gambling Health Test), GAD-2 (Generalized Anxiety Disorder 2-item), GHQ (General Health Questionnaire), MIST (Multi-item short screening tool), MOS SF-36 (MOS 36-item Short-Form Health Survey), NODS CLIP (The National Opinion Research Center DSM Screen for Gambling Problems (NODS) Control, Lying and Preoccupation Measure), NODS-PERC (The NODS Preoccupation, Escape, Chasing and Risked Relationships Measure), PGSI (Problem Gambling Severity Index), PRIME-MD (Primary Care Evaluation of Mental Disorders), SF-12vs (Short-Form Health Survey, Version 2), SF-36 (Short Form 36), SISQ (Single-item screening question for unhealthy drug use), SOGS (South Oaks Gambling Screen) 

Table 2: Study estimates and meta-analysis results

\begin{tabular}{|l|l|l|l|l|}
\hline \multicolumn{1}{|c|}{ Study } & \multicolumn{1}{|c|}{$\mathbf{n}$} & \multicolumn{1}{|c|}{ Country } & \multicolumn{1}{|c|}{ Screen } & $\begin{array}{l}\text { Prevalence of } \\
\text { Problem } \\
\text { Gambling }\end{array}$ \\
\hline Cowlishaw et al., (2017) & 1058 & UK & PGSI & $\mathbf{0 . 9 \%}$ \\
\hline Elley et al., (2014) & 265 & Canada & CHAT & $\mathbf{2 . 0 \%}$ \\
\hline Goodyear-Smith et al., (2006) & 2543 & New Zealand & MIST & $\mathbf{3 . 2 \%}$ \\
\hline Goodyear-Smith et al., (2008) & 995 & New Zealand & SOGS & $\mathbf{1 . 8 \%}$ \\
\hline Goodyear-Smith et al., (2009) & 755 & New Zealand & SOGS & $\mathbf{0 . 7 \%}$ \\
\hline Goodyear-Smith et al., (2013) & 233 & New Zealand & eCHAT & $\mathbf{1 . 1 \%}$ \\
\hline Morasco et al., (2006) & 574 & US & SOGS & $\mathbf{1 5 . 7 \%}$ \\
\hline Nehlin et al., (2016) & 537 & Sweden & NODS PERC & $\mathbf{6 . 3 \%}$ \\
\hline Pasternak \& Fleming (1999) & 1051 & US & SOGS & $\mathbf{6 . 2 \%}$ \\
\hline Sullivan et al., (2007) & 1580 & New Zealand & EIGHT & $\mathbf{7 . 5 \%}$ \\
\hline & $\begin{array}{l}\text { Weighted } \\
\text { mean } \\
(\mathbf{9 5 \%} \text { CI) }\end{array}$ & & & $\mathbf{3 . 0 \%}$ \\
$\mathbf{I}^{\mathbf{2}}$ & & & $\mathbf{1 . 6 \%}$ to 5.6\% \\
\hline
\end{tabular}

'Problem gambling is classed here as scoring 5+ on the PGSI and 3+ on the SOGS (South Oaks Gambling Screen).

CHAT (Case-finding and Help Assessment Tool), eCHAT (Electronic version of the Case-finding and Help Assessment Tool), EIGHT (Early Intervention Gambling Health Test), MIST (Multi-item short screening tool), MOS SF-36 (MOS 36-item Short-Form Health Survey), NODS-PERC (The NODS Preoccupation, Escape, Chasing and Risked Relationships Measure), PGSI (Problem Gambling Severity Index), SOGS (South Oaks Gambling Screen) 
Table 3: Subgroup analyses

\begin{tabular}{|c|c|c|c|c|}
\hline \multirow{2}{*}{ Study characteristic } & \multirow{2}{*}{ k } & \multirow{2}{*}{$\begin{array}{c}\text { Mean } \\
\text { estimate }\end{array}$} & \multicolumn{2}{|c|}{$95 \% \mathrm{Cl}$} \\
\hline & & & LE & UB \\
\hline \multicolumn{5}{|l|}{ Length of measurement } \\
\hline Brief & 4 & $3.0 \%$ & $1.6 \%$ & $5.3 \%$ \\
\hline Extended & 6 & $3.2 \%$ & $1.2 \%$ & $8.1 \%$ \\
\hline \multicolumn{5}{|l|}{ Decade of publication } \\
\hline Pre-2010 & 6 & $3.9 \%$ & $1.7 \%$ & $8.7 \%$ \\
\hline Post-2010 & 4 & $2.0 \%$ & $0.9 \%$ & $4.5 \%$ \\
\hline \multicolumn{5}{|l|}{ International jurisdiction } \\
\hline North America & 3 & $6.1 \%$ & $2.3 \%$ & $15.5 \%$ \\
\hline Other & 7 & $2.3 \%$ & $1.2 \%$ & $4.4 \%$ \\
\hline
\end{tabular}


Figure 1: PRISMA flow diagram: Flow of information through the different phases of the systematic review
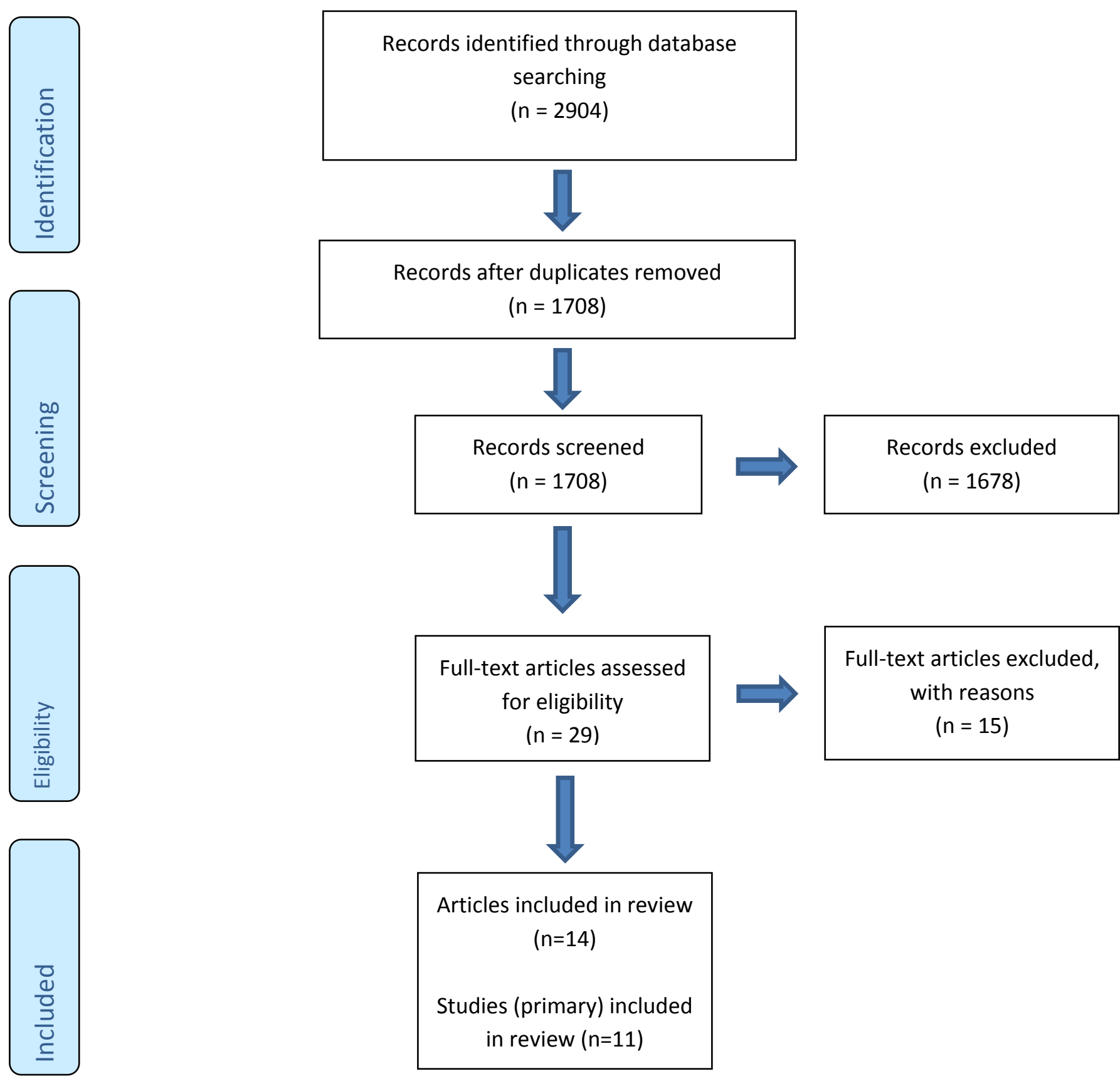

Full-text articles assessed for eligibility $(n=29)$

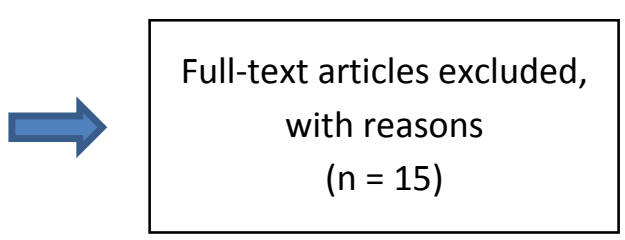

Articles included in review $(n=14)$

Studies (primary) included in review $(n=11)$ 
Figure 2: Studies reporting rates of problem gambling

Study

Cowlishaw 2017

Elley 2014

Goodyear-Smith 2006

Goodyear-Smith 2008

Goodyear-Smith 2009

Goodyear-Smith 2013

Morasco 2006

Nehlin 2016

Pasternak 1999

Sullivan 2007

Fixed effect model

Random effects model

Heterogeneity: $I^{2}=97 \%, \tau^{2}=0.9997, p<0.01$

Events Total

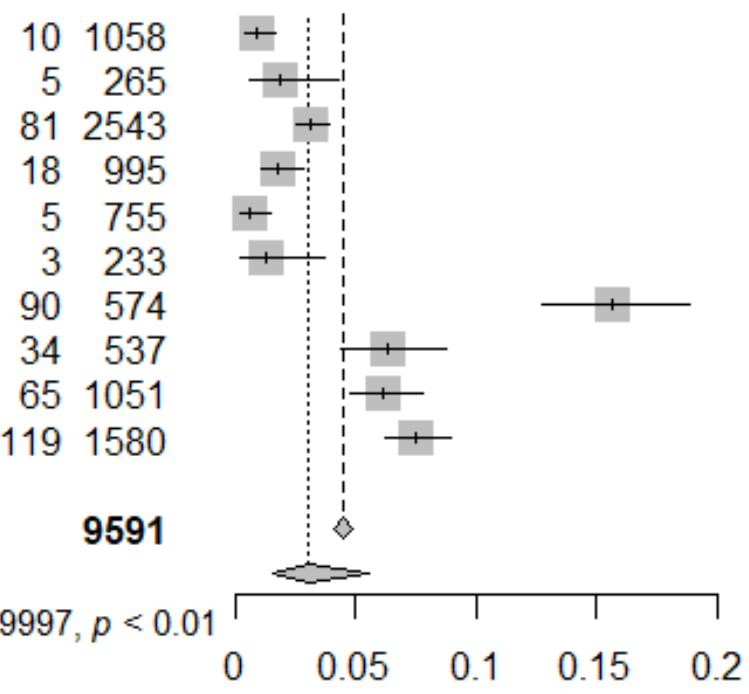

Proportion $\quad 95 \%-\mathrm{Cl}$

$0.01 \quad[0.00 ; 0.02]$

$0.02[0.01 ; 0.04]$

$0.03 \quad[0.03 ; 0.04]$

$0.02[0.01 ; 0.03]$

$0.01 \quad[0.00 ; 0.02]$

$0.01 \quad[0.00 ; 0.04]$

$0.16[0.13 ; 0.19]$

$0.06 \quad[0.04 ; 0.09]$

$0.06 \quad[0.05 ; 0.08]$

$0.08 \quad[0.06 ; 0.09]$

$0.04[0.04 ; 0.05]$

$0.03[0.02 ; 0.06]$ 